\title{
Phylogenetic analysis of Pneumocystis from pig lungs obtained from slaughterhouses in southern and midwestern regions of Brazil
}

\author{
[Análise filogenética de Pneumocystis obtidos de pulmões de suínos provenientes de abatedouros \\ da região Sul e Centro Oeste do Brasil] \\ E.M.C. Sanches ${ }^{1,2}$, L. Ferreiro ${ }^{1}$, M.R. Borba ${ }^{1}$, A. Spanamberg ${ }^{1}$, A.P. Ravazzolo ${ }^{1}$, J.M. Santurio ${ }^{3}$, \\ D. Driemeir ${ }^{1}$, D.E.S.N. Barcellos ${ }^{1}$, M. Berthelemy ${ }^{4}$, J. Guillot $^{4}$ \\ ${ }^{1}$ Faculdade de Veterinária - Universidade Federal do Rio Grande do Sul \\ Av. Bento Gonçalves, 9090 \\ 90540-000 - Porto Alegre, RS \\ ${ }^{2}$ Universidade Federal de Mato Grosso and Secretaria de Estado de Saúde - Cuiabá, MT \\ ${ }^{3}$ Laboratório de Pesquisas Micológicas - Universidade Federal de Santa Maria - UFSM - Santa Maria, RS \\ ${ }^{4}$ Parasitology-Mycology Service, UMR INRA, AFSSA, ENVA, UPVM BIPAR \\ Ecole Nationale Vétérinaire d'Alfort (ENVA) - Maisons-Alfort, France
}

\begin{abstract}
The Pneumocystis genus is comprised of pathogens dwelling in the lungs of terrestrial, aerial, and aquatic mammals. Occasionally they induce severe pneumonitis, particularly in hosts with severe impairment of the immune system and progressively may fill pulmonary alveolar cavities causing respiratory failure. Molecular genetic studies revealed that Pneumocystis gene sequences present a marked divergence with the host species concerned. In the present study, the genetic diversity of Pneumocystis obtained from lungs of swines was examined by analyzing mitochondrial large subunit (mtLSU) and small subunit (mtSSU) rRNA sequences. The samples were obtained from two slaughterhouses located in two Brazilian states. Phylogenetic analysis demonstrated that genetic groupings within Pneumocystis organisms were in accordance with those of the corresponding hosts and that two clusters were formed. In conclusion, these data show that there are genetically distinct porcine Pneumocystis genotypes with at least two separate clusters in Brazil.
\end{abstract}

Keywords: swine, Pneumocystis, phylogeny, mitochondrial large subunit, small subunit, rRNA

\section{RESUMO}

O gênero Pneumocystis compreende patógenos que residem em pulmões de animais terrestres, aéreos e aquáticos. Pode ocasionar uma grave pneumonia, particularmente em hospedeiros com o sistema imunológico seriamente comprometido, o que ocorre por meio de uma progressiva disseminação nas cavidades alveolares, causando insuficiência respiratória. Estudos genéticos, baseados em métodos moleculares, revelaram que as sequências dos genes de Pneumocystis apresentam marcante divergência de acordo com a espécie de hospedeiro. Neste estudo, a diversidade genética das amostras obtidas a partir de pulmões de suínos, provenientes de dois abatedouros localizados em dois estados brasileiros, foi examinada por análise das sequencias dos nucleotídeos dos produtos de PCR dos genes mtLSU e mtSSU do rRNA do Pneumocystis. O resultado confirma a tendência registrada em pesquisas com amostras de outros animais e permite concluir que existem, pelo menos, dois grupos filogenéticos distintos de Pneumocystis de suínos no Brasil.

Palavras-chave: Pneumocystis, suínos, filogenia, mitochondrial large subunit (mtLSU) rRNA, small subunit (mtSSU) rRNA

Recebido em 11 de agosto de 2010

Aceito em 12 de agosto de 2011

E-mail: cavallini.sanches@ufrgs.br 


\section{INTRODUCTION}

Pneumocystis is a group of organisms assigned to the Fungal Kingdom (Edman et al., 1988; Wakefield et al., 1992; Calderon-Sandubete et al., 2002). The genus comprises pathogens dwelling in the lungs of terrestrial, aerial, and aquatic mammals (Laakkonem e Sukura, 1997; Mazars et al., 1997; Laakkonem, 1998; Guillot et al., 1999; Durand-Joly et al., 2000; Demanche et al., 2001; Guillot et al., 2001; Laakkonem et al., 2001). Occasionally they induce severe pneumonitis, particularly in hosts with severe impairment of the immune system. In such hosts, Pneumocystis species develop progressively and may fill pulmonary alveolar cavities, a process that leads to respiratory failure (Dei-Cas, 2000).

Molecular genetic studies revealed that Pneumocystis gene sequences (mtLSU rRNa, $m t S S U$ rRNA, ITS, DHPS, and MSG) present a marked divergence with the host species concerned. Numerous Pneumocystis gene fragments from humans and other primates, rodents, rabbits and insectivores have been compared. Consistently it was found that specific sequences could be attributed to pathogens from different hosts (Banerji et al., 1995; Mazars et al., 1995; Wakefield, 1998; Laakkonen, 1998; Denis et al., 2000; Durand-Joly et al., 2000; Guillot et al., 2001).

A more recent study in primates showed that a large sequence divergence in mitochodrial ribossomal DNA subunits (mtLSU rRNA) among Pneumocystis species was correlated with the phylogeny of their hosts. This observation, which could be extended to other mammals (Demanche et al., 2001; Guillot et al., 2001), suggests that cophylogeny can explain the current distribution of pathogens in their hosts (Hugot et al., 2003).

The high divergence among Pneumocystis species probably results from a prolonged process of coevolution with each mammal host and is mostly associated with cospeciation (Hugot et al., 2003).

The present paper focuses on a Pneumocystis species identified through aligned DNA sequences of two genes mtLSU-rRNA and a small subunit of mitochondrial ribosomal RNA ( $m t S S U-r R N A$ ) from lung samples of swine slaughtered in the regions of Porto Alegre, RS, and Cuiabá, MT, Brazil.

\section{MATERIALS AND METHODS}

The lung tissue samples were obtained from two slaughterhouses in separate regions of Brazil. Those from the Southern state of Rio Grande do Sul were designated RS, and those from the mid-western state of Mato Grosso were designated MT. Pig lungs were examined; those with lesions were identified and the areas taken by lesions were measured and recorded as percent of the total lung. Among 281 lungs collected in RS, 142 (50.5\%) showed macroscopic signs of inflammation and consolidation of different grades of pneumonia. Likewise, among 283 lungs obtained in MT, 141 (49.8\%) lungs showed similar lesion patterns. The overall rate of Pneumocystis positive samples detected was $36.9 \%$ (39.9\% in RS and $33.9 \%$ in $\mathrm{MT}$ ). Collected lung tissue samples were frozen after macroscopic examination and stored at $-20^{\circ} \mathrm{C}$ for DNA extraction (Cavallini Sanches et al., 2006; 2007).

For Pneumocystis DNA extraction and PCR a small part of the lung tissue (from 250mg) was then finely minced, homogenized through crushing and analyzed with the Kit Qiagen (Dneasy ${ }^{\mathrm{TM}}$ tissue Kit, Qiagen, Courtaboeuf, France). DNA was extracted from 34 randomly selected samples of frozen lung tissues of 208 swine with Pneumocystis previously detected by Grocott and Immunohistochemical analysis. The presence of Pneumocystis DNA was determined by nested PCR at the mtLSU rRNA gene and a small subunit of mitochondrial ribosomal RNA (mtSSU-rRNA). For gene amplification (mtLSU-rRNA), the primer sets pAZ102HpAZ102E and pAZ102X/R1-pA102ZY/R1 were used. Thermocycling conditions for the first PCR round were as follows: each cycle consisted of denaturation for $1.30 \mathrm{~min}$ at $94^{\circ} \mathrm{C}$, annealing for $1.30 \mathrm{~min}$ at $55^{\circ} \mathrm{C}$, and extension for $2 \mathrm{~min}$ at $72^{\circ} \mathrm{C}$; 40 cycles were included in the protocol. The second round of PCR was performed with the primer pair pAZ102Y/R1 and pAZ102X/R1. Ten amplification cycles were carried out at $94^{\circ} \mathrm{C}$ for $1.30 \mathrm{~min}, 55^{\circ} \mathrm{C}$ for $1.30 \mathrm{~min}$, and $72^{\circ} \mathrm{C}$ for $2 \mathrm{~min}$, followed by 30 cycles at $94^{\circ} \mathrm{C}$ for $1.30 \mathrm{~min}, 63^{\circ} \mathrm{C}$ for $1.30 \mathrm{~min}$, and $72^{\circ} \mathrm{C}$ for $2 \mathrm{~min}$. Expected product sizes were approximately 350bp and 230bp for the first and second rounds of PCR, respectively (Cavallini Sanches et al., 2007).

For the amplification of the mtSSU-rRNA gene, the primer sets pAZ102 10F-RI -pAZ102 10R-RI and pAZ102 13-RI -pAZ10214-RI were used in primary PCR. Thermocycling conditions for the first PCR round were as follows: each cycle 
consisted of denaturation for $2 \mathrm{~min}$ at $94^{\circ} \mathrm{C}$, annealing for $1.30 \mathrm{~min}$ at $55^{\circ} \mathrm{C}$, and extension for $2 \mathrm{~min}$ at $72^{\circ} \mathrm{C}$; 40 cycles were included in the protocol. The second round of PCR was performed with the primer pair pAZ102 13-RI pAZ10214-RI. Ten amplification cycles were carried out at $94^{\circ} \mathrm{C}$ for $1.30 \mathrm{~min}, 52^{\circ} \mathrm{C}$ for 1.30 min, and $72^{\circ} \mathrm{C}$ for $2 \mathrm{~min}$, followed by 30 cycles at $94^{\circ} \mathrm{C}$ for $1.30 \mathrm{~min}, 63^{\circ} \mathrm{C}$ for $1.30 \mathrm{~min}$, and $72^{\circ} \mathrm{C}$ for $2 \mathrm{~min}$. Expected product sizes were approximately 400bp and 300bp for the first and second rounds of PCR, respectively.

Amplification products were directly sequenced from both ends using the sets of internal primers on an automated DNA sequencer (GenomeExpress, Montreuil, France) at École Nationale Vétérinaire d'Alfort, Maison-Alfort, France.

For each species, Pneumocystis mtSSU and $m t L S U$ rRNA sequences were combined. The sequences were initially aligned with the computer program CLUSTAL X (version 1.63b, December 1997) and then through visual optmization with a computer program using SeAl version $0.1 \quad$ (available on http://envolve.zoo.ox.ac.uk/). Regions that contained alignment ambiguities were systematically excluded from the phylogenetic analysis. Both the branch-and-bound and heuristic search options in the Phylogenetic Analysis Using Parsimony Program (PAUP 4.0) were used for comparison of sequence alignments and generation of parsimonious trees. The strength of the internal branches from the resulting trees was statistically tested by bootstrap analysis using 500 bootstrap replications.

\section{RESULTS AND DISCUSSION}

The sequences of genes for ribosomal RNA are particularly valid due to the codifying regions that are found in all organisms. The small subunit of ribosomal RNA (16S-like rRNAs) has gained importance due to the acceptance by inference of reliable structures for phylogenetic analyses. This region (16S rRNA) is formed by mosaics of genetic elements which show specific rates of evolutionary mutation (Edman et al., 1994).

In this report, the genetic diversity of Pneumocystis from swine is examined by analyzing mitochondrial large subunit (mtLSU) and small subunit ( $m t S S U$ ) rRNA sequences.

The phylogenetic analysis demonstrated that genetic groupings within Pneumocystis organisms were in accordance with those of the corresponding hosts. After results from all analysis performed (neighbor joining, heuristic search and branch and bound), two clusters were observed. The first cluster was composed of Pneumocystis organisms from PN25P and PN64P swine in Porto Alegre and Cuiabá regions. The second cluster was composed of Pneumocystis organisms of 32 swine (PN7C, PP6C, PP82P, PP50C, PP107C, PN4C, PN67P, PP65, PN105P, PN36, PN73P, PN80P, PP77P, PPCBA46, PPPOA38, PN86P, PN5P, PPCBA6, PP69C, PPPOA65, PPPOA61, PP38, PN117, PNPOA56, PNPOA9, PN91P, PPBA69, PN76P, PP5C, PPCBA50, PN59, PP102), from the same distinct geographical regions.

In the first cluster, swine without macroscopic lesions in lungs and the second cluster were either with or without pneumonia.

The use of mitochondrial genes as phylogenetic markers shows that in the mtSSU rRNA gene supported by a bootstrap value (Fig. 1) and $m t L S U$ rRNA was supported by a variable (low) bootstrap value (Fig. 2).

These data constitute the first report on Pneumocystis colonizing the lungs of pigs in Brazil, also showing that porcine Pneumocystis sp. are genetically distinct, suggesting the existence of two clusters of the agent in the pig. However, it was not possible to determine whether the samples characterized in this study are related to distinct geographical regions or to any specific weather pattern, or are associated with any other variable, requiring further investigation to uncover such pending questions. The sequences found in the study corroborate with the ones also found by others, which relate different Pneumocystis sequences, in the same host such as man, primates, rats and bats. 


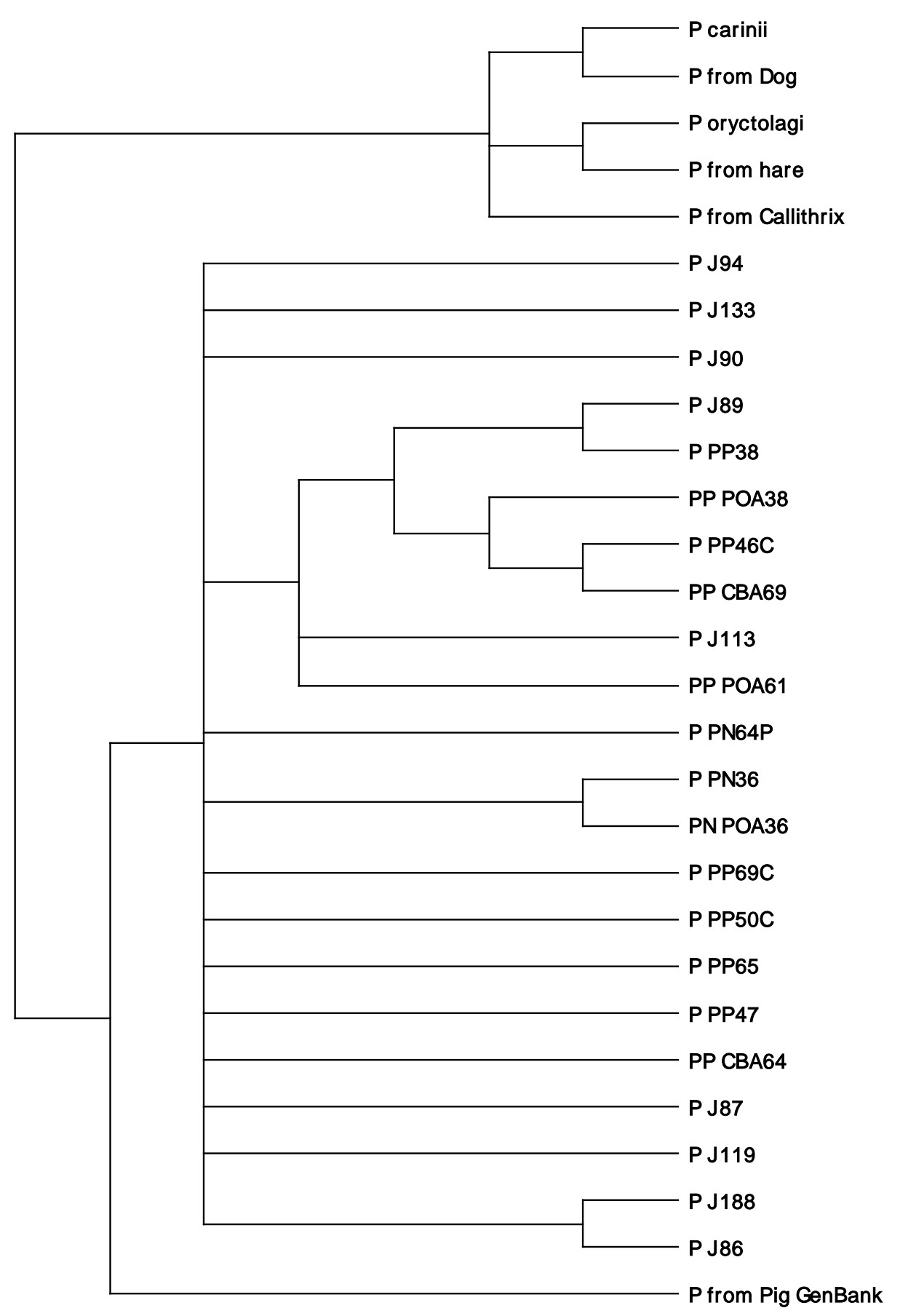

Figure 1. Phylogenetic relationships of Pneumocystis organisms from swine inferred from mtLSU rRNA sequences. The phylogram presented resulted from bootstrapped data sets obtained through parsimony analysis (heuristic search option in PAUP 4.0). The percentages above the branches are the frequencies with which a given branch appeared in 500 bootstrap replications. P PN: Pneumocystis from swine with normal lungs; P PP: Pneumocystis from swine of lungs with macroscopic pneumonia; C and CBA: samples from Cuiabá (MT); P and POA: samples from Porto Alegre (RS); P J: Pneumocystis from wild boar (Sus scrofa). 


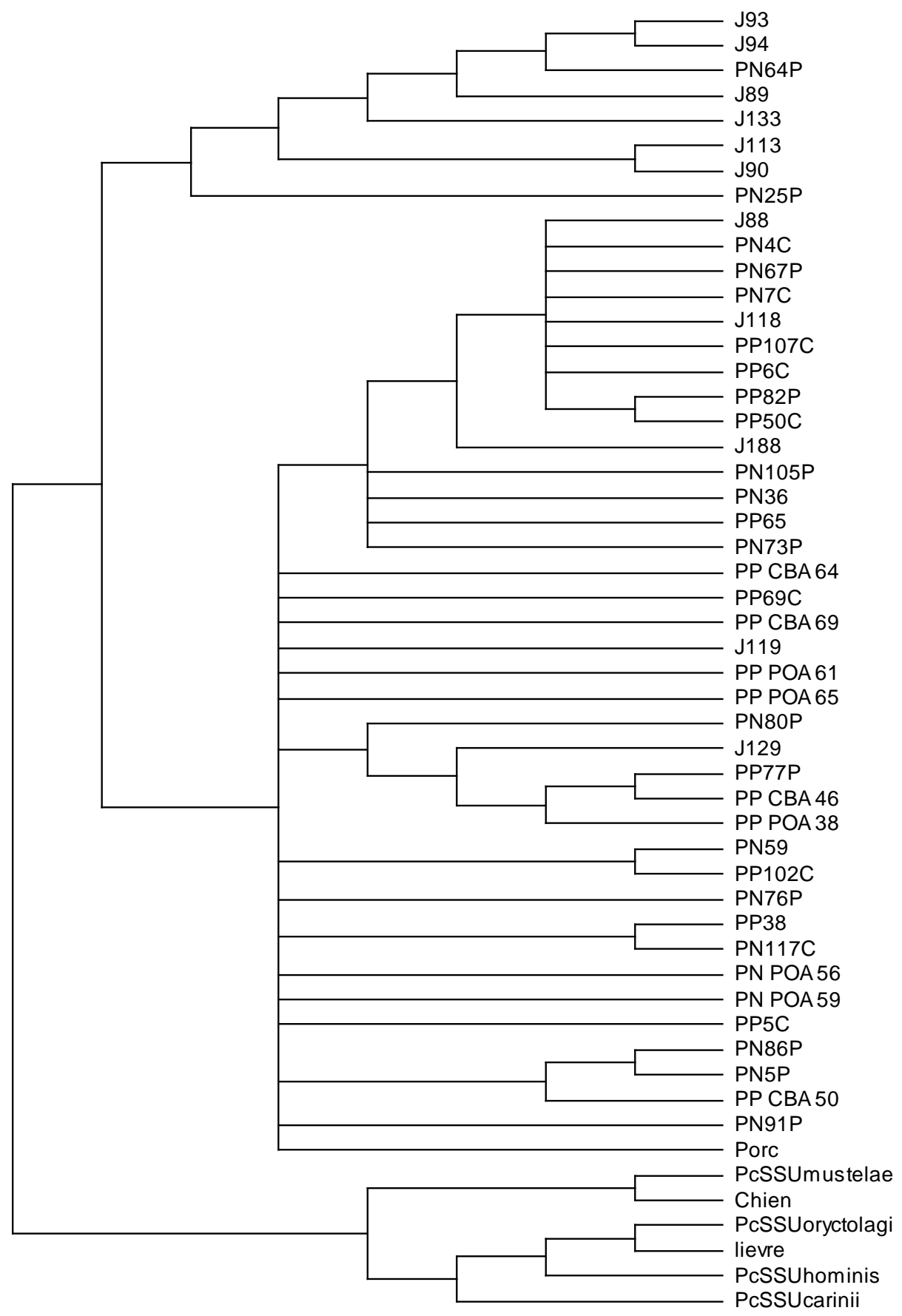

Figure 2. Phylogenetic relationships of Pneumocystis organisms from swine inferred from $m t S S U$ rRNA sequences. The phylogram presented resulted from bootstrapped data sets obtained through parsimony analysis (heuristic search option in PAUP 4.0). The percentages above the branches are the frequencies with which a given branch appeared in 500 bootstrap replications. P PN: Pneumocystis from swine of normal lungs; P PP: Pneumocystis from swine of lungs with macroscopic pneumonia; C and CBA: samples from Cuiabá (MT); P and POA: samples from Porto Alegre (RS); P J: Pneumocystis from wild boar (Sus scrofa). 


\section{ACKNOWLEDGMENTS}

The authors thank Marilia T. O. Belmonte, Angela R. Belmontede Souza, Aline Schmitt, Clarissa Silveira Luiz Vaz, Laura de Almeida, Eliana Franco Lopes, Priscila Zlotowski, Ana O. Wallwitz, Roberto Medeiros, MAPA-SIPAMT, Judi M. Nóbrega, Plínio L. Lopes, and Antônio F. Barbosa Filho for their assistance. This work was supported by a grant (Processo165 472409/2004-02) from the Conselho Nacional de Desenvolvimento Científico e Tecnológico166 (CNPq), Brazil.

\section{REFERENCES}

BANERJI, S.; LUGLI, E.B.; MILLER, R.F.; WAKEFIELD, A.E. Analysis of genetic diversity at the arom locus in isolates of Pneumocystis carinii. J. Eukaryot. Microbiol., v.42, p.675-679, 1995.

CALDERON-SANDUBETE, E.J.; VARELAAGUILAR, J.M.; MEDRANO-ORTEGA, F.J. et al. Historical perspective on Pneumocystis carinii infection. Protist., v.153, p.303-310, 2002.

CAVALLINI SANCHES, E.M.; BORBA, M.R.; SPANAMBERG, A. et al. Co-Infection of Pneumocystis carinii f.sp. suis and Porcine Circovirus-2 (PCV2) in Pig Lungs obtained from slaughterhouses in southern and midwestern regions of Brazil. J. Eukaryot. Microbiol., v.53, p.S92-S93, 2006.

CAVALLINI SANCHES, E.M.; PESCADOR, C.; ROZZA D. et al. Detection of Pneumocystis spp. in lung samples from pigs in Brazil. Med. Mycol., v.45, p.395-399, 2007.

DEI-CAS, E. Pneumocystis infections: the iceberg ? Med Mycol., v.38, p.23-32, 2000.

DEMANCHE, C.; BERTHELEMY, M.; PETIT, T. et al. Phylogeny of Pneumocystis carinii from 18 primate species confirms host specificity and suggests coevolution. J. Clin. Microbiol., v.39, p.2126-2133, 2001.

DENIS, C.M.; MAZARS, E.; GUYOT, K. et al. Genetic divergence at the SODA locus of six different formae speciales of Pneumocystis carinii. Med. Mycol., v.38, p.289-300, 2000.

DURAND-JOLY, I.; WAKEFIELD, A.E.; PALMER, R. et al. Ultrastructural and molecular characterization of Pneumocystis carinii isolated from a rhesus monkey (Macaca mulatta). Med Mycol., v.38, p.61-72, 2000.
EDMAN, J.C.; SOGIN, M.L. Molecular phylogeny of Pneumocystis carinii. In: WALZE, P.D. Pneumocystis carinii pneumonia. 2nd ed. New York: editora ou [s.n.], 1994. p.91-103.

EDMAN, J.C.; KOVACS, J.A.; MASUR, H. et al. Ribossomal RNA sequence shows Pneumocystis carinii to be a member of the fungi. Nature, v.334, p.519-522, 1988.

GUILLOT, J.; CHEVALIER, V.; QUENEY, G. et al. Acquisition and biodiversity of Pneumocystis carinii in a colony of wild rabbits (Oryctolagus cuniculus). J. Eukaryot. Microbiol., v.46, p.100S101S, 1999.

GUILLOT, J,; DEMANCHE, R.; HUGOT, J.P. et al. Parallel phylogenies of Pneumocystis species and their mammalian hosts. J. Eukaryot. Microbiol., v.47, p.113S-115S, 2001.

HUGOT, J.P.; DEMANCHE, C.; BARRIEL, V. et al. Phylogenetic systematics and evolution of primate-derived Pneumocystis based on mitochondrial or nuclear DNA sequence comparison. Syst Biol., v.52, p.735-744, 2003.

LAAKKONEM, J.; SUKURA, A. Pneumocystis carinii of the common shrew, Sorex araneus, shows a discrete phenotype. J. Eukaryot. Microbiol., v.44, p.117-121, 1997.

LAAKKONEN, J. Pneumocystis carinii in wildlife. Int. J. Parasitol., v.28, p.241-251, 1998.

LAAKKONEN, J.; FISHER, R.N.; CASE, T.J. Pneumocystosis in wild small mammals from California. J. Wild Dis., v.37, p.408-412, 2001.

MAZARS, E.; ODBERG-FERRAGUT, C.; DEICAS, E. et al. Polymorphism of the thymidylate synthase gene of Pneumocystis carinii from different host species. J. Eukaryot. Microbiol., v.42, p.26-32, 1995.

MAZARS, E.; GUYOT, K.; FOURMAINTRAUX, S. et al. Detection of Pneumocystis in European wild animals. J. Eukaryot. Microbiol., v.44, p.39S, 1997.

WAKEFIELD, A.E.; PETERS, S.E.; BANERJ, S. et al. Pneumocystis carinii shows DNA homology with the ustomycetous red yeast fungi. Mol. Microbiol.,v.6, p.1903-1911, 1992.

WAKEFIELD, A.E.; STRINGER, J.R.; TAMBURRINI, E.; DEI-CAS, E. Genetics, metabolism and host specificity of Pneumocystis carinii. Med. Mycol., v.36, p.183-193, 1998. 